\title{
Ultrasound in the Assessment of Tumor Response in the Age of Targeted and Immuno-Oncology Therapies. Back to the Future
}

\author{
Ultraschall zur Bewertung des Tumor-Ansprechens im Zeitalter der zielgerichteten \\ Therapien und der Immunonkologie - Zurück in die Zukunft („Back to the Future“)
}

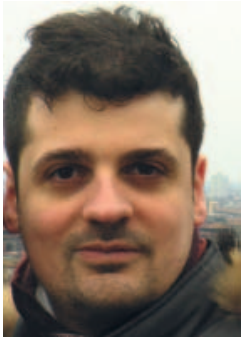

Francesco Tovoli

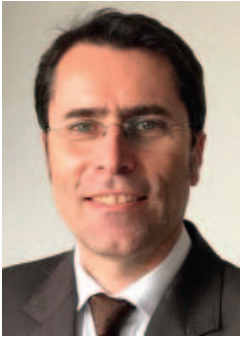

Fabio Piscaglia

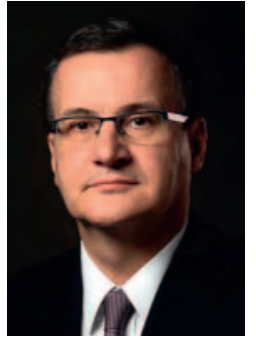

Boris Brkljacic

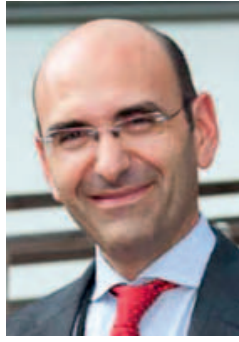

Vito Cantisani
Correspondence

Dr. Vito Cantisani

Department of Radiology, Sapienza-University of Rome,

Viale Regina Elena 324, 00161 Rome, Italy

Tel.: ++ 39/3471743947

Fax: ++ 39/064455602

vito.cantisani@uniroma1.it
Bibliography

DOI https://doi.org/10.1055/a-0834-8353

Published online: 2019

Ultraschall in Med 2019; 40: 129-131

(c) Georg Thieme Verlag KG, Stuttgart · New York

ISSN 0172-4614
In Oncology, ultrasound has been long considered among the least convincing imaging techniques to evaluate response to chemoteraphy. The inter-operator variability, reduced panoramic view, and the impossibility of providing information about lung and bones were justified reasons for considering computed tomography (CT), magnetic resonance imaging (MRI) and positron emission tomography (PET) as superior techniques compared to ultrasound imaging (US). But should we accept this message as unequivocal and true for every possible clinical setting in Oncology and most importantly even for any future scenario? Most likely not. Inspite of the above mentioned limitations, US techniques have become able to provide additional informations that are complementary to those provided by other techniques. Our readers could undoubtedly think that this merit belongs to the technological development of that the ultrasound techniques have experienced in recent years, including contrast enhanced ultrasound and sonoelastography [1-3]. However, while this thought is undoubtedly correct, this paradigm shift is in addition derived from the parallel progress in the development of new anticancer drugs. The conventional cytotoxic regimens, whose efficacy is measured according to the extent of tumour shrinkage, have become flanked or replaced by targeted therapies that achieve disease stabilisation with a reduced rate of objective responses. Most often, this effect mirrors a reduction in intratumoral microvascular blood flow. Different clinical trials have evaluated the possibility of correlating CEUS parameters and clinical response to these new agents. Indeed, a correlation was demonstrated for patients with renal cell carcinoma (RCC) treated with sunitinib [4] and sorafenib [5, 6], for patients with hepatocellular carcinoma (HCC) treated with bevacizumab [7] and sorafenib [8], and for patients with liver metastases from neuroendocrine tumours [9]. In the case of HCC, CEUS obtained using vascular endothelial growth factor receptor-2 (VEGFR-2) targeted microbubbles was also explored in a murine model, resulting in a potential imaging modality to discriminate sorafenib responders and non-responders [10].

In the present issue of Ultraschall in der Medizin, Kim et al. reported the results of a study investigating CEUS as a tool to assess the response to target therapies in breast cancer. [11] Their results show the potential of CEUS also in breast cancer treatment evaluation, and confirm the promising preliminary results experiences highlighted obtained in murine xenograft models [12]. These techniques, however, are still underutilised in patients receiving anti-HER2 therapies such as lapatinib and trastuzumab, especially in the neoadjuvant setting [13].

We could, therefore, answer our initial question about the relevance of US imaging in Oncology by concluding that US techniques are suitable to have an increasingly important role because of their capacity to early evaluate functional, rather than morphological changes of tumour response. Nevertheless, we need to take into consideration that oncological treatment is advancing and changing rapidly, and immunotherapy resulted in 
the new paradigm shift in oncology, with the development of the immune checkpoint inhibitors. These drugs have drastically changed the therapeutic scenario of melanoma and non-small cell lung carcinoma. Positive evidence also emerged from the treatment of RCC, HCC and triple-negative breast cancer. The immune checkpoint inhibitors induce an objective and often long lasting response $15-20 \%$ of treated patients. They are also currently under investigation in many different cancer types and in combinations among them and with Tyrosin Kinase Inhibitors.

Consequently, the accurate measurement of tumour shrinkage becomes again of pivotal importance in a "back to the future" scenario. The already mentioned limitations of US imaging would seem therefore to be a sad prelude to its return to a marginal role. The availability of new automatic and semiautomatic software to assess tumour volume using 3D-CT imaging represent a considerable progress in this sense [14]. However, fortunately for ultrasound enthusiasts (which hopefully include our readers as well), also new US techniques are developing in parallel, also thanks to the more powerful computational capacity of computer workstations embedded in US scanners, and there is now the possibility to assess tumour response utilising 3D-printed tumour models from US images, with a quality similar to that achievable from the same models obtained from CT images [15]. Obviously much work is still needed, but the potential to combine CEUS, elastography and most importantly 3D-US with automatic reconstruction of the tumor volume and contrast perfusion in one single equipment with high computational capacity is a good prelude to a significant contribution of US in this field. In fact, the need for early assessment of response of target lesions is still high, given the paucity of biomarkers for response, the extremely high costs of new combination tumor therapies and the persistence of a significant rate of non-responders.

To this end US remains the ideal modality for early and interval treatment assessment tool due to its safety and accessibility, but only provided that the expectations about technological advancements will be fulfilled, so that future development will bring US back to dimensional, but this time highly reproducible assessment.

\section{Ultraschall zur Bewertung des Tumor-} Ansprechens im Zeitalter der zielgerichteten Therapien und der Immunonkologie Zurück in die Zukunft ( „Back to the Future“)

In der Onkologie wurde Ultraschall sehr lange als das am wenigsten überzeugendste bildgebende Verfahren für die Bewertung des Ansprechens auf die Chemotherapie angesehen. Berechtigte Gründe hierfür waren die Variabilität zwischen den Bedienern, das eingeschränkte Sichtfeld und die Unmöglichkeit, Informationen über Lunge und Knochen zu erhalten, sodass Computertomografie (CT), Magnetresonanztomografie (MRI) und die Positronen-Emissions-Tomografie (PET) dem Ultraschall (US) gegenüber als überlegen galten. Aber müssen wir diese Aussage als unbestreitbar und richtig akzeptieren angesichts aller möglichen klinischen Umfelder in der Onkologie? Und was noch wichtiger ist:
Gilt dies auch für alle Zukunft? Höchstwahrscheinlich nicht. Trotz der oben genannten Einschränkungen können US-Techniken inzwischen, in Ergänzung zu anderen Verfahren, Zusatzinformationen liefern. Unsere Leser werden zweifellos vermuten, dass diese Leistung mit der technologischen Entwicklung der sonografischen Methoden in den letzten Jahren einhergeht, einschließlich dem Einsatz des kontrastverstärkten Ultraschalls (CEUS) und der Sono-Elastografie für diagnostische und interventionelle Zwecke [1 - 3]. Während dieser Gedanke allerdings zweifellos richtig ist, kommt dieser Paradigmenwechsel auch durch die parallel verlaufende Entwicklung neuer Krebsmedikamente zustande. Die herkömmlichen zytotoxischen Behandlungsschemata, deren Wirksamkeit anhand des Ausmaßes der Tumorschrumpfung gemessen wird, wurden durch zielgerichtete Therapien (,targeted therapies“) flankiert oder ersetzt, die durch eine niedrigere objektive Ansprechrate eine Stabilisierung der Erkrankung erreichen. Meistens spiegelt sich dieser Effekt in einer Verringerung des mikrovaskulären Blutflusses innerhalb des Tumors wider. In verschiedenen klinischen Studien wurde eine mögliche Korrelation von CEUS-Parametern und des klinischen Ansprechens auf diese neuen Wirkstoffe bewertet. In der Tat wurde eine Korrelation nachgewiesen, und zwar für Patienten mit Nierenzellkarzinom (RCC), die mit Sunitinib [4] und Sorafenib [5, 6] behandelt wurden, für Patienten mit hepatozellulärem Karzinom (HCC) unter Therapie mit Bevacizumab [7] und Sorafenib [8] sowie für Patienten mit Lebermetastasen bei neuroendokrinen Tumoren [9]. Bei HCC wurde darüber hinaus CEUS unter Verwendung von vaskulären endothelialen Wachstumsfaktor-Rezeptor-2 (VEGFR2) -spezifischen Microbubbles in einem HCC-Mausmodell untersucht mit dem Ergebnis, dass dies ein mögliches bildgebendes Verfahren sein könnte, mit dem Sorafenib-Responder und NichtResponder unterschieden werden können [10].

In der vorliegenden Ausgabe der „Ultraschall in der Medizin“ berichtete Kim et al. über eine Studie, die CEUS als Methode zur Beurteilung des Ansprechens auf zielgerichtete Therapien bei Brustkrebs untersuchte [11]. Die Ergebnisse zeigen die Leistungsfähigkeit von CEUS auch bei der Bewertung der Therapie von Mammakarzinomen und bestätigen die vielversprechenden vorläufigen Ergebnisse im Maus-Xenograft-Modell [12]. Diese Techniken werden jedoch bei Patienten, die Anti-HER2-Therapien wie Lapatinib und Trastuzumab erhalten, insbesondere auf dem Gebiet der neoadjuvanten Therapien immer noch nicht ausreichend genutzt [13].

Hiermit können wir unsere Eingangsfrage nach der Bedeutung der US-Bildgebung in der Onkologie beantworten, indem wir zu dem Schluss kommen, dass sonografische Techniken, aufgrund ihrer Fähigkeit eher funktionelle als morphologische Änderungen des Tumoransprechens zu bewerten, geeignet sind, eine zunehmend wichtigere Rolle einzunehmen. Trotzdem müssen wir berücksichtigen, dass die onkologische Behandlung rasch voranschreitet und sich schnell verändert und dass die Immuntherapie mit der Entwicklung von Immuncheckpoint-Inhibitoren zu einem neuen Paradigmenwechsel in der Onkologie geführt hat. Diese Medikamente haben das therapeutische Szenario bei Melanomen und nichtkleinzelligen Bronchialkarzinomen drastisch verändert. Positive Evidenz zeigte sich auch bei der Behandlung von RCC, HCC und triple-negativem Mammakarzinom (,triple-negative 
breast cancer“). Die Immuncheckpoint-Inhibitoren führen zu einem objektiven und häufig langanhaltenden Ansprechen bei $15-20 \%$ der behandelten Patienten. Sie werden derzeit auch bei vielen verschiedenen Krebsarten und in Kombinationen untereinander sowie mit Tyrosin-Kinase-Inhibitoren untersucht.

Folglich ist die genaue Messung der Tumorschrumpfung in einem „Back to the Future"-Szenario wieder von zentraler Bedeutung. Die bereits erwähnten Einschränkungen der US-Bildgebung sind daher augenscheinlich der traurige Auftakt für dessen Rückkehr zur Nebenrolle. Die Verfügbarkeit neuer automatischer und semiautomatischer Software zur Beurteilung des Tumorvolumens mittels 3D-CT-Bildgebung stellt in dieser Hinsicht einen erheblichen Fortschritt dar [14]. Zum Glück für die Ultraschall-Enthusiasten (zu denen hoffentlich auch unsere Leser gehören) entwickeln sich auch neue US-Techniken parallel, auch dank der leistungsfähigeren Rechenleistung der Computerarbeitsplätze, die in die US-Geräte integriert sind. Darüber hinaus besteht jetzt die Möglichkeit, das Ansprechen des Tumors zu bewerten, indem man 3D-gedruckte Tumormodelle aus US-Bildern verwendet, und zwar in einer ähnlich guten Qualität, wie sie bei den gleichen, aus CT-Bildern generierten Modellen erzielt wird [15]. Offensichtlich ist noch viel Arbeit nötig, aber die Möglichkeit der Kombination von CEUS, Elastografie und vor allem 3D-US mit automatischer Rekonstruktion des Tumorvolumens und Kontrastperfusion in einem einzigen Gerät mit hoher Rechenleistung ist ein guter Auftakt für einen signifikanten Beitrag des US auf diesem Gebiet. In der Tat besteht ein hoher Bedarf, das Ansprechen von Zielläsionen frühzeitig zu beurteilen, angesichts des Mangels an Biomarkern für das Ansprechen, der extrem hohen Kosten neuer onkologischer Kombinationstherapien und der bestehenden signifikanten Non-Responder-Rate.

Zu diesem Zweck bleibt US aufgrund seiner Sicherheit und leichten Zugänglichkeit die ideale Methode für die Beurteilung der Früh- und Intervallbehandlung - allerdings nur unter der Voraussetzung, dass die Erwartungen an den technologischen Fortschritt erfüllt werden, sodass die zukünftige Entwicklung den US zurückbringt zu einer dimensionalen, aber diesmal gut reproduzierbaren Bewertung.

\section{Reference}

[1] Dietrich CF, Lorentzen T, Appelbaum L et al. EFSUMB Guidelines on Interventional Ultrasound (INVUS), Part III - Abdominal Treatment Procedures (Short Version). Ultraschall in Med 2016; 37: 27 -45. doi: 10.1055/s0035-1553965. Epub 2016 Feb 12

[2] Sidhu PS, Cantisani V, Dietrich CF et al. The EFSUMB Guidelines and Recommendations for the Clinical Practice of Contrast-Enhanced Ultrasound (CEUS) in Non-Hepatic Applications: Update 2017 (Short Version).
Ultraschall in Med 2018; 39: 154-180. doi: 10.1055/s-0044-101254. Epub 2018 Mar 6

[3] Dietrich CF, Bamber J, Berzigotti A et al. EFSUMB Guidelines and Recommendations on the Clinical Use of Liver Ultrasound Elastography, Update 2017 (Short Version). Ultraschall in Med 2017; 38: 377- 394. doi: 10.1055/s-0043-103955. Epub 2017 Apr 13

[4] Lassau N, Koscielny S, Albiges L et al. Metastatic renal cell carcinoma treated with sunitinib: early evaluation of treatment response using dynamic contrast-enhanced ultrasonography. Clin Cancer Res 2010; 16: $1216-1225$

[5] Lamuraglia M, Escudier B, Chami L et al. To predict progression-free survival and overall survival in metastatic renal cancer treated with sorafenib: pilot study using dynamic contrast-enhanced Doppler ultrasound. Eur J Cancer 2006; 42: 2472-2479

[6] Escudier B, Lassau N, Angevin E et al. Phase I trial of sorafenib in combination with IFN alpha-2a in patients with unresectable and/or metastatic renal cell carcinoma or malignant melanoma. Clin Cancer Res 2007; 13 : $1801-1809$

[7] Lassau N, Koscielny S, Chami L et al. Advanced hepatocellular carcinoma: early evaluation of response to bevacizumab therapy at dynamic contrast-enhanced US with quantification-preliminary results. Radiology 2011; 258: 291-300

[8] Zocco MA, Garcovich M, Lupascu A et al. Early prediction of response to sorafenib in patients with advanced hepatocellular carcinoma: the role of dynamic contrast enhanced ultrasound. J Hepatol 2013; 59: 10141021

[9] Lin X, Chen J, Xu M et al. Application of Parametric Contrast-Enhanced Ultrasound for Early Treatment Response Evaluation in Metastatic Hepatic Neuroendocrine Neoplasm (abstract 189 (18)). ENETs annual conference 2017 https://www.enets.org/application-of-parametric-contrastenhanced-ultrasound-for-early-treatment-response-evaluation-in-meta static-hepatic-neuroendocrine-neoplasm.html

[10] Baron Toaldo M, Salvatore V, Marinelli S et al. Use of VEGFR-2 Targeted Ultrasound Contrast Agent for the Early Evaluation of Response to Sorafenib in a Mouse Model of Hepatocellular Carcinoma. Mol Imaging Biol 2015; 17: 29-37

[11] Kim SH, Lee YJ, Kim Y] et al. Contrast-Enhanced Ultrasound for Early Prediction of Response of Breast Cancer to Neoadjuvant Chemotherapy. Ultraschall in Med 2019; 40: 194-204

[12] Wei X, Li Y, Zhang S et al. Ultrasound Targeted Apoptosis Imaging in Monitoring Early Tumor Response of Trastuzumab in a Murine Tumor Xenograft Model of Her-2-Positive Breast Cancer. Transl Oncol 2014; 7: $284-291$

[13] Di Cosimo S, Campbell C, Azim HA et al. The use of breast imaging for predicting response to neoadjuvant lapatinib, trastuzumab and their combination in HER2-positive breast cancer: Results from Neo-ALTTO.

[14] Bargellini I, Scionti A, Mismas V et al. Identification of responders to sorafenib in hepatocellular carcinoma: is tumor volume measurement the way forward? Oncology 2014; 86: $191-198$

[15] Choi YR, Kim JH, Park SJ et al. Therapeutic response assessment using 3D ultrasound for hepatic metastasis from colorectal cancer: Application of a personalized, 3D-printed tumor model using $C T$ images. PloS One 2017; 12: e0182596 